\title{
Analyzing Competitive Advantages on the Basis of Resource-based View: The Concept of Price and Non-price Factors"
}

\author{
Maja Makovec Brenčič**
}

In the paper the author analyses the contemporary issues of gaining competitive advantages (CAs) at the firm level. The basic purpose of the paper is to develop theoretical and empirical analysis of non-price (invisible, intangible, non-traditional) factors (sources) of firm competitiveness. In author's opinion non-price factors present the base of vital importance for a successful firm performance nowadays. The paper introduces a research of the selected non-price factors (human resource, knowledge, innovation, quality, environment and location, time) in the Slovenian export manufacturing companies, which showed that the concept of price and non-price factors of CAs can be accepted as a contemporary mechanism of defining sources of CAs at firm level.

Im folgenden Aufsatz werden gegenwärtige Ausgangspunkte für das Erzielen von Konkurrenzvorteilen durch Unternehmen analysiert. Das Ziel dieses Beitrages ist die Durchführung einer theoretischen und empirischen Analyse der nicht-preislichen (unsichtbaren, immateriellen, nicht traditionellen) Faktoren (Quellen) der Konkurrenzfähigkeit eines Unternehmens. Nach der Meinung der Autorin stellen die nicht-preislichen Faktoren heutzutage die wichtigste Grundlage für den erfolgreichen Geschäftsverkehr eines modernen Unternehmens dar. Der Aufsatz befasst sich im speziellen mit ausgewählten nicht-preislichen Faktoren (Menschenquellen, Kenntnisse, Innovationen, Qualität, Umwelt und Standort, Zeit) in slowenischen Exportverarbeitungsunternehmen. Im Ergebnis wird aufgezeigt, dass das Konzept der nichtpreislichen und preislichen Faktoren der Konkurrenzvorteile einen geeigneten und sinnvollen Mechanismus für das Definieren von Quellen für Konkurrenzvorteile auf Unternehmensniveau darstellt.

\footnotetext{
* manuscript received: 28.09.2000, revised: 14.06.2001, accepted: 20.06.2001;

** Makovec Brenčič, Maja; born in 1969; senior lecturer in International Business, International Marketing and Marketing Management at the Faculty of Economics, University of Ljubljana. Major areas of research interest: competitiveness (macro and micro), competitive advantages, textiles, case development.
} 


\section{Introduction}

One of the fundamental questions facing contemporary firms is how to gain and maintain CAs on international markets. Looking back into the works of Penrose (1959), Lippman and Rumelt (1982), Nelson and Winter (1982), Wernerfelt (1984), Barney (1986), Conner (1991), Peteraf (1993) and others, or contemporary resource-advantage theory developed by Hunt (1995a, 1997a,b,c) and Hunt and Morgan (1995, 1996), the resource-based view provides an acceptable framework for developing and defining CAs. The concept of defining resources as tangible and intangible entities that enable a firm to produce products or services which can be successfully implemented on the markets, gives firms a reliable mechanism for understanding which of the many resources are important in terms of gaining CA. Even more, in my opinion resource-advantage theory represents the most acceptable way to define CAs on international markets nowadays. The main reason for this is the importance of intangibles/invisibles - non-price factors - which differentiate the position and implementation of CAs on markets. Non-price factors, based on competencies and skills, are the most important sources of CA of the firm. From this point of view we can define some of the many sources of CA which directly and indirectly influence the position and performance of the firm on international markets. In the paper I divide these sources into six groups: human resource, knowledge, environment and location, time (flexibility), innovation, quality. All factors are interdependent, directly and indirectly influence each other and also the implementation of CA on the markets. Among these factors human resource is the most important, central factor (human resource theory; Pffefer, 1994 etc.) which influences the effectiveness of all other factors. Each of the factors is defined and measured by several variables based on resource-advantage theory of competition.

It is a well-known fact that today the so-called price factors (as basic factors of production) are spread around more evenly than they used to be (I do not deny that endowments of basic production factors still influence CAs, but with a less direct role than in the past). Nevertheless we all are also aware that non-price factors severely influence the position and implementation of CA of the firm at present and in the near future the non-price factors are to become even more important in gaining and maintaining advantages than the basic price factors. However, it also holds true that attempts to prove their increasing importance are scarce. The reason for this is not hidden only in the problem of their definition but also in the fact that they are hard to measure, vary enormously and develop constantly. Furthermore, today we do not raise only the question of what CAs consist of but also what competitive advantages actually are. In terms of their definition and measurement there is still no prevailing definition or variable most appropriate for their measurement, which is understandable due to their dynamic development. Probably one of the reasons for this lies in the increasing influence of non-price factors. 
All mentioned above presents the main reasons for measuring the influence of the non-price factors on CAs in export firms. I carried out the research in Slovenian export manufacturing firms. The main purpose was to verify the concept of price and non-price factors of CA based on the issues of resourceadvantage theory and to measure the influence of the selected non-price factors on the advantages implemented on the international markets. Despite the measurement limits (limited number of variables and factors included in the research, problems of defining the dependent variable (CA) etc.), the research brought some interesting (mostly expected) results and showed that the concept of price and non-price factors of CAs can be accepted as a contemporary mechanism of defining sources of CAs in export firms.

\section{Theoretical Background}

Despite the constant presence and influence of non-price factors in international business only late 70-ies made their role more visible in the studies of export strategies and competitiveness of firms. The NEDO report 1965 (Hughes, 1993), Piercy (1982), Aldington Report (1985), European Management Forum (1984) etc. started to analyze price and non-price competitiveness of exporting firms. The classical competitiveness studies (cost competition) were upgraded step by step by non-price issues of competition, including marketing intangibles associated with added values of various kinds. The NEDO report for example mentioned non-price variables such as design, quality, delivery, selling, styling, speed, after sales service etc. Even before, in early 70-ies Kravis and Lipsey (1971) in their classic study of international competitiveness came to the conclusion that "relative export prices lost their force in the real marketplace because of the surrounding factors which reduce the impact of price«. Therefore non-price competitiveness became one of the most important ways of gaining success on international markets. This does not mean that price factors have not played an important role in international competition, but much less than in the past. Since products on markets became more and more differentiated (rather than substitutable), customers started to rank product factors such as quality, delivery, timing etc. much higher in competition than the price. Therefore $»$ the distinction between price and non-price competitiveness became basic for the discussion of export strategy« (Piercy, 1982) - and gaining competitive advantage.

In 90-ies and at the turn of the millennium non-price factors have played even more important role than before. Their variety and the dynamic development of new or differentiated non-price factors make them not only hardly recognizable but often inimitable. The influence of trustworthiness, tacit knowledge, other specific knowledge embedded in human resource, flexibility, unofficial information, relationships with suppliers, customers etc. are important factors of export competitiveness. Their role in the contemporary theory of CA can be 
best explained with the issues of resource-based view developed by Barney (1991), Conner (1991), Grant (1991), Peteraf (1993), Oliver (1997), and others, especially with the recently developed resource-advantage (R-A) theory of competition (Hunt (1995a,b; 1997a,b,c); Hunt and Morgan (1995, 1999)). The recent (R-A) theory can theoretically ground the concept of non-price factors, because it expands the view of resources and includes all intangible entities in the firm - from specific skills, dynamic (distinctive) capabilities to specific resources. Therefore it does not ground only the theory of relationship marketing (Hunt, 1997a) but it (despite the inward focus) also provides a framework to analyze performance on international markets (Broderick et al., 1998).

Transparent issues of R-A theory can be seen in the following figures, which show the contemporary mechanism of gaining and maintaining CAs, developed by Hunt and Morgan (1995, 1996). Following these issues the concept of price/non-price factors can be in may opinion defined as a modern concept of competitive advantages at the firm level.

Figure 1: A Schematic of the Resource-advantage Theory of Competition

Societal Sources

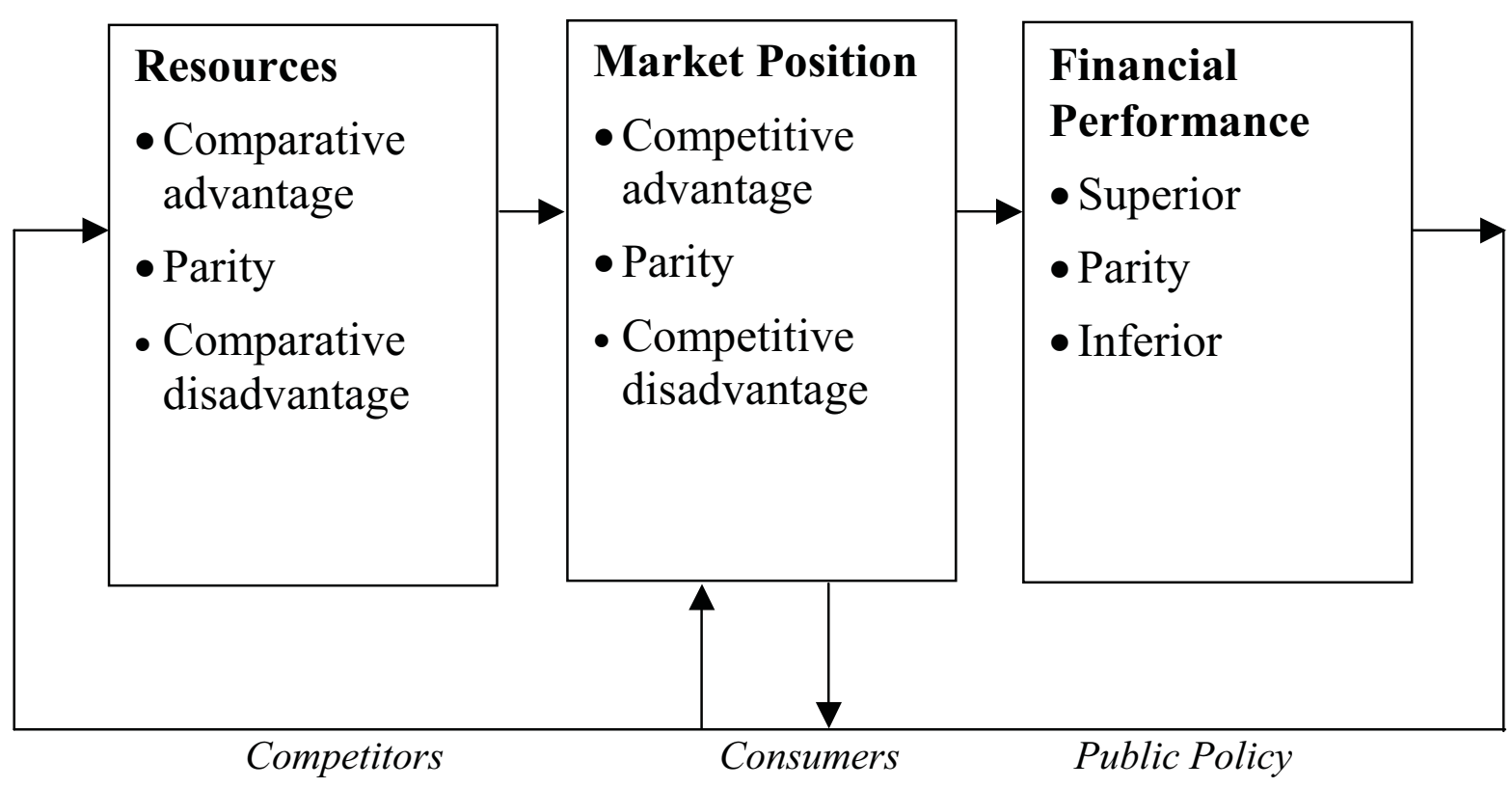

Source: Hunt and Morgan, 1996. 
Figure 2: The Matrix of Market Position in R-A Theory

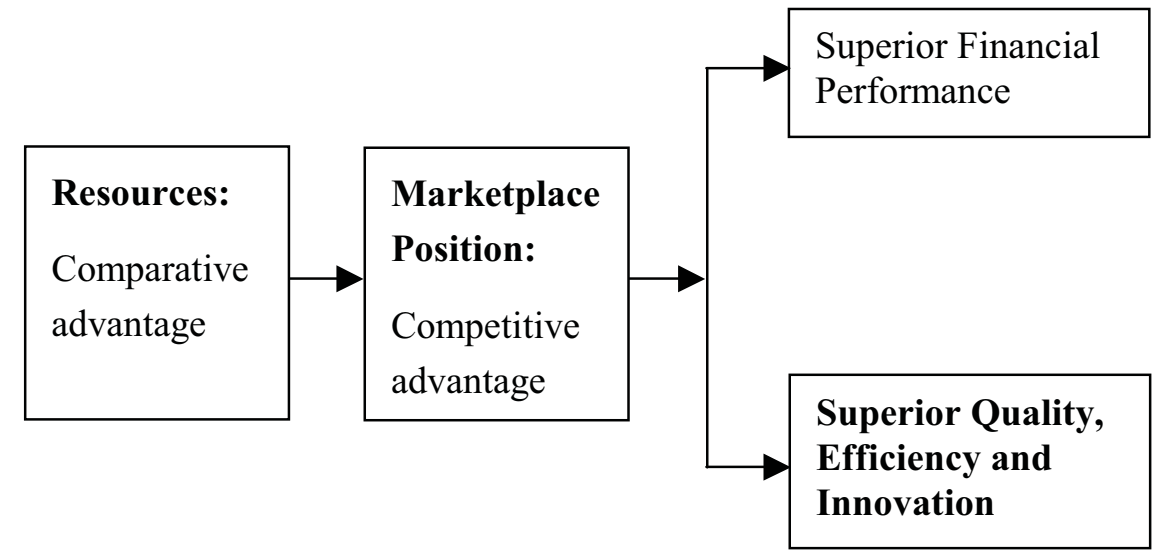

\section{Source: Hunt and Morgan, 1995}

The definition of the non-price factors originates in their nature (Itami and Rhoel, 1987; Hall, 1991,1992; Barney, 1991 etc.): majority of them are invisible and intangible; hard to evaluate and accumulate; they are usually rare or specifically developed within the firm or group of firms; inimitable; without real substitute; hardly mobile (or immobile); they are capable of simultaneous multiple uses; they are both inputs and outputs of business activities; they present the base for sustainable CAs. But to become a source of CA they must be valuable or enable creation of value (Fahy, Smithee 1999), otherwise they are not a potential source of advantage (Barney, 1991).

Figure 3: The Concept of Price and Non-price Factors of CA

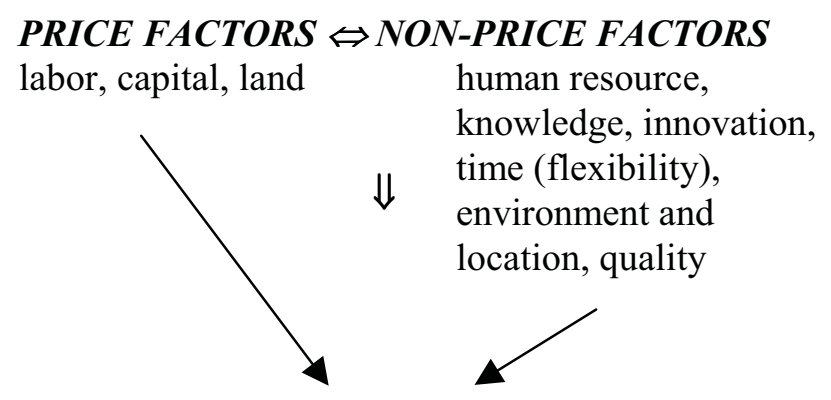

COMPETITIVE ADVANTAGES OF THE FIRM

It is extremely difficult to classify or divide these factors in any way. Not only because of their variety but also because of their constant development and dynamic differentiation. Barney (1991) accepts the categorization of resources of the firm as physical capital resources, human capital resources and organizational capital resources; Hall (1992) defines them as resources which are assets (patents, copyright, registered designs etc.) and skills (know-how, culture); Andriani and Hall (1998) speak about regulatory, positional, functional and cultural intangible resources etc. So far no unified or prevailing categorization of the sources of CA has been verified which is understandable 
due to dynamic developments of firm capabilities, skills and constant differentiation of resources. Therefore I categorized non-price factors of CA in six most important groups as shown in the following figure.

\section{The Research Framework}

After the pilot research and testing of questionnaires the research started in October 1999, when questionnaires were mailed to 321 export manufacturing companies in Slovenia. Manufacturing and exporting were two criteria for the sample frame. (The majority of companies had over $70 \%$ of sales in exporting in 1998). With the response rate of $38 \%$ (122 questionnaires) at the end of January 2000 the research was completed.

The structure of the respondents by the industry was as follows (see Table 1).

Table 1: The Structure of the Respondent Companies by Industry (Manufacturing ${ }^{1}$ )

\begin{tabular}{|l|c|c|}
\hline Manufacturing & Frequency & $\%$ \\
\hline Food, beverages and tobacco & 6 & 4.92 \\
\hline Textiles and textile products & 22 & 18.03 \\
\hline Leather and leather products & 4 & 3.28 \\
\hline Wood and wood products & 4 & 3.28 \\
\hline Paper, publishing and printing & 6 & 4.92 \\
\hline Coke, petroleum, products and nuclear fuel & 0 & 0.00 \\
\hline Chemicals, products and man-made fibers & 10 & 8.20 \\
\hline Rubber and plastic products & 4 & 3.28 \\
\hline Other non-metal, mineral products & 4 & 3.28 \\
\hline Basic metals and fabricated products & 19 & 15.57 \\
\hline Machinery and equipment nec. & 17 & 13.93 \\
\hline Electrical and optical equipment & 19 & 15.57 \\
\hline Transport equipment & 0 & 0.00 \\
\hline Other manufacturing & 7 & 5.74 \\
\hline Total & 122 & 100.00 \\
\hline
\end{tabular}

The questionnaire consisted of nine sections considering factor groups, and two open questions about CAs of firms and their export performance. The majority of questions were measured by Likert scale (1 to 5), answered either by top

\footnotetext{
${ }^{1}$ Because of relativelly low response rate (by number of the respondents) in a certain industry the statistical analysis was made for the whole manufacturing sector and not for a separate industry.
} 
executive in marketing or sales. The basic research question was what (and to what extent) are the influences of the selected price and non-price factors on competitive advantages of export firms. According to this research challenge I developed and tested the following basic research hypotheses:

H1: The price and non-price factors of CAs are interdependent.

H2: The selected non-price factors (human resource, knowledge, quality, environment and location, innovation, time (flexibility) have in this contemporary marketing environment stronger influence on CAs than the price factors.

H3: Non-price and price factors influence CAs separately (as a single factor) and as a group (price and non-price).

\subsection{Non-price Factors and Their Measurements}

All variables defining a selected factor were developed on the grounds of R-A theory and export competitiveness of a firm. For each of the variable there is either theoretical or empirical test in the literature, which proves its importance or connection to CA theory and export success. With this eclectic approach I combined the factor defining variables in the measurement framework.

The human resource factor was measured through several variables (majority is based on R-A and HR theory): rareness, inimitability, substitutability and immobility of HR in a firm (Prahalad, Hamel, 1990; Barney, 1991; Conner, 1991; Pfeffer, 1994); motivation and goals of HR (commitment to international business) (Buckley et.al, 1988); corporate culture (Barney, 1986, Hall, 1991, 1992; Bharadway et al., 1993); flexibility and adaptation of HR to environment changes (Dyer, 1993; Hall, 1993); capabilities of management (Dierickx, Cool, 1989; Day, Nedungadi, 1994; Mahoney, 1995). Knowledge was measured by the share of tacit knowledge in a firm (Teece, 1998; Andriani, Hall 1998; Dyer in Singh, 1998), by the share of accepted codified knowledge in industry (Teece, 1998; Andriani, Hall, 1998) and by the assessment of the importance of knowledge for product development (Hall, 1993). Innovation was defined by the share of the profit invested in R\&D (IMD (Institute for Management Development); WEF (World Economic Forum); Belcher et al., 1996; Shapiro, 1989), by the number of registered patents, trademarks, labels, know-how (Shapiro, 1989; Hall, 1993; Huseman, Goodman, 1999), by the structure of innovation (technological, organizational, managerial etc.) (Zahra, 1999), by the assessment of innovation capabilities in a firm and by the development of formal and informal networking with customers, suppliers and others (relationship marketing theory; Gummesson, 1994; Broderick et al., 1999). 
Environment and location (localization) were measured by adaptation to environment obstacles; and by the level of localization of home based capabilities and skills (Porter, Dunning, Teece, 1998). Quality was defined by the quality of the product and its reliability (Hall, 1993; Rao, 1998; Gale, 1994) and by the quality as a constant process within and outside of a firm (Cole et al., 1993; Feigenbaum, 1992/93). Time (flexibility) was defined by the responsiveness of HR to changes (flexibility of HR in a firm); and by the time reagibility of all the processes in a firm (Vives, 1990; Glazer, 1991 etc.).

\subsection{Price Factors and Their Measurements}

Price-factors (production factors: labor, capital, land) were selected and defined on the grounds of long prevailing cost competitiveness theory (Kravis, Lipsey, 1971; Balassa, 1985; Tyson 1984; Thurow, 1992 etc.). All three factors were measured in their relative sense - by the comparison of the costs of their major competitors on the most important market.

\subsection{Dependent Variable $=$ Competitive Advantage (CA)}

The limitations referring to selected factors and their variables were not the only ones. Even bigger challenge represents a definition of CA - how can we define it as a dependent variable. According to prevailing export theories and R-A theory I defined CA as a dependent variable with three variables:

- By the share of exports in total sales (Kravis and Lipsey, 1992; Aaby and Slater, 1989 etc.);

- By the market share on the most important market (Buckley et al., 1988; Diamantopoulus, 1999 etc.); and

- By the return on equity (ROE)(R-A theory).

\section{Results of the Statistical Analysis}

The analysis brought some interesting results.

Firstly, positive and statistically significant correlation between separate nonprice (knowledge, innovation etc.) and price factors showed their dependency and their unconditional linkage (see Table 2). Only in the case of correlation between LO/LC, LO/HR, LO/TI and TI/PP we cannot find statistically significant dependency ${ }^{2}$. All correlations are thus positive and the majority is

\footnotetext{
${ }^{2}$ According to the statistic results location was among all factors the most difficult to evaluate and shows some discrepancies in their understanding and meaning - despite the fact that pilot testing did not show any problems in the evaluation of this particular factor.
} 
also statistically significant. This means that we can accept the first research hypothesis (H1) and define the interdependency among selected price and nonprice factors.

Table 2: Correlation between Price and Non-price Factors

\begin{tabular}{|l|c|c|c|c|c|c|c|c|c|c|}
\hline & KN & HR & IN & QY & TI & EN & PP & CC & LO & LC \\
\hline KN & 1.000 & .651 & .672 & .483 & .121 & .227 & .269 & .319 & .086 & .367 \\
\hline P* $^{*}$. & .000 & .000 & .000 & .188 & .013 & .003 & .000 & .350 & .000 \\
\hline HR & & 1.000 & .670 & .389 & .263 & .282 & .217 & .144 & .026 & .172 \\
\hline P* & &. & .000 & .000 & .004 & .002 & .017 & .116 & .779 & .059 \\
\hline IN & & & 1.000 & .346 & .207 & .373 & .150 & .381 & .172 & .212 \\
\hline P* & & &. & .000 & .023 & .000 & .100 & .000 & .060 & .019 \\
\hline QY & & & & 1.000 & .432 & .317 & .349 & .439 & .197 & .428 \\
\hline P* & & & &. & .000 & .000 & .000 & .000 & .030 & .000 \\
\hline TI & & & & & 1.000 & .315 & .053 & .369 & .051 & .315 \\
\hline P* & & & & &. & .000 & .562 & .000 & .582 & .000 \\
\hline EN & & & & & & 1.000 & .057 & .360 & .452 & .060 \\
\hline P* & & & & & &. & .537 & .000 & .000 & .514 \\
\hline PP & & & & & & & 1.000 & .228 & .000 & .414 \\
\hline P* & & & & & & &. & .012 & .128 & .000 \\
\hline CC & & & & & & & & 1.000 & .206 & .530 \\
\hline P* & & & & & & & &. & .024 & .000 \\
\hline LO & & & & & & & & & 1.000 & .016 \\
\hline P* & & & & & & & & &. & .860 \\
\hline LC & & & & & & & & & & 1.000 \\
\hline P* & & & & & & & & & &. \\
\hline
\end{tabular}

*Sig. 2-tailed; $\mathrm{P} \leq 0.05$

Non-price factors: KN-knowledge; HR-human resource; IN-innovation; QYquality; TI-time; EN-environment; LO-location. Price factors: CC- capital costs; LC - labor costs, PP-price of the product ${ }^{3}$

Secondly, the statistical analysis also proved that non-price and price factors influence CAs in all three cases of the selected dependent variables (see Table

\footnotetext{
${ }^{3} \mathrm{PP}$ is here defined as a price factor to control the understanding of price vs. non-price issues of competitiveness.
} 
3). I could not weight the contribution of price or non-price factors directly, because of the lack of some variable data. However, the analysis proved that:

- The firms, which evaluated non-price factors above and price factors below the average, gain higher CAs on international markets (see Table $4 \mathrm{a}, \mathrm{b}$, c; arithmetic mean comparison).

All correlations between non-price factors and dependent variables are positive whereas the correlations between price factors and dependent variables are negative or none (see Table 3). But we can only accept statistically significant correlation between knowledge and export share. All other correlations were statistically insignificant.

According to open question ("Quote your most important source of CA in a firm?") the quality of the product was ranked before the price of the product in $86 \%$ of the cases.

All these results show that $\mathrm{H} 2$ can be accepted although we cannot directly measure the influence weight of the non-price or price factor group to CAs.

Table 3: Correlation between Price and Non-price Factors and Dependent Variables (CA)

\begin{tabular}{|l|c|c|c|c|c|c|c|c|c|c|c|}
\hline & & KN & HR & IN & QY & TI & EN & PP & CC & LO & LC \\
\hline EXPORT 98 & $\mathrm{r}$ & .172 & .088 & .144 & .140 & .071 & .125 & -.140 & -.039 & .097 & -.042 \\
\hline & $\mathrm{P}$ & .031 & .169 & .058 & .064 & .219 & .088 & .064 & .338 & .147 & .323 \\
\hline ROE & $\mathrm{r}$ & .138 & .233 & .135 & .223 & .142 & .171 & -.045 & .117 & .029 & .107 \\
\hline & $\mathrm{P}$ & .068 & .055 & .073 & .007 & .063 & .033 & .314 & .104 & .377 & .123 \\
\hline MARKET SHARE & $\mathrm{r}$ & .110 & .118 & .073 & .271 & .129 & .110 & -.025 & -.064 & .135 & -.059 \\
\hline & $\mathrm{P}$ & .157 & .139 & .250 & .005 & .116 & .158 & .408 & .278 & .107 & .295 \\
\hline
\end{tabular}

$P$ - Sig. 1-tailed; $P \leq 0.05 ; r$ - correlation coefficient; ROE - return on equity; MARKET SHARE - market share for major product group on the most important market; EXPORT 98 - the share of exports in total sales; all data for 1998 
Table 4a: The Importance of Price and Non-price Factors According to the Export Share

\begin{tabular}{|l|c|c|c|c|c|c|c|c|c|c|}
\hline GROUP & KN & HR & IN & QY & TI & EN & PP & CC & LO & LC \\
\hline 1.00 & 5.3158 & 4.8947 & 4.4737 & 6.2105 & 5.8421 & 3.2105 & 6.1579 & 4.8947 & 3.5789 & 5.5789 \\
\hline 2.00 & 5.6977 & 5.3023 & 4.9302 & 5.9535 & 6.0698 & 4.3023 & 5.9535 & 4.6047 & 4.1328 & 5.4186 \\
\hline 3.00 & 5.9298 & 5.3966 & 5.1207 & 6.3621 & 6.2241 & 4.2857 & 5.8276 & 4.5614 & 4.1679 & 5.1552 \\
\hline Total & 5.7583 & 5.2810 & 4.9504 & 6.1983 & 6.1157 & 4.1261 & 5.9091 & 4.6500 & 4.0496 & 5.3306 \\
\hline
\end{tabular}

\section{Groups:}

1. Export share 0-40\% (of total sales in 1998)

2. Export share 41-70 \% (of total sales in 1998)

3. Export share $71-100 \%$ (of total sales in 1998)

Table 4b: The Importance of Price and Non-price Factors According to the Return on Equity

\begin{tabular}{|l|c|c|c|c|c|c|c|c|c|c|}
\hline GROUP & KN & HR & IN & QY & TI & EN & PP & CC & LO & LC \\
\hline 1.00 & 5.5641 & 5.0000 & 4.6000 & 6.0500 & 5.9250 & 3.5500 & 5.9500 & 4.6875 & 3.8250 & 5.4250 \\
\hline 2.00 & 5.8519 & 5.4198 & 5.1235 & 6.2716 & 6.2099 & 4.4177 & 5.8889 & 4.5750 & 4.1605 & 5.2840 \\
\hline Total & 5.7583 & 5.2810 & 4.9504 & 6.1983 & 6.1157 & 4.1261 & 5.9091 & 4.6500 & 4.0496 & 5.3306 \\
\hline
\end{tabular}

1 - Firms with ROE below the average in the industry

2 - Firms with ROE above the average in the industry

Table 4c: The Importance of Price and Non-price Factors According to the Market Share

\begin{tabular}{|l|c|c|c|c|c|c|c|c|c|c|}
\hline GROUP & KN & HR & IN & QY & TI & EN & PP & CC & LO & LC \\
\hline 1.00 & 5.6304 & 5.3404 & 5.0213 & 5.9787 & 6.1702 & 4.1522 & 5.9787 & 4.8511 & 4.0638 & 5.4468 \\
\hline 2.00 & 5.9000 & 5.5000 & 5.2250 & 6.5000 & 6.3250 & 4.5641 & 5.8500 & 4.6250 & 4.2250 & 5.3000 \\
\hline Total & 5.7583 & 5.2810 & 4.9504 & 6.1983 & 6.1157 & 4.1261 & 5.9091 & 4.6500 & 4.0496 & 5.3306 \\
\hline
\end{tabular}

1. Firms with the market share below the average share on the most important market (in the industry or product group)

2. Firms with the market share above the average share on the most important market (in the industry or product group)

Thirdly, I developed a factor analysis (PAF method; OBLIMIN rotation). Five non-price factors out of all non-price variables were defined (they account for 
$58.4 \%$ of the total variability): innovation/time (flexibility); knowledge; quality; location and human resource (see Table 5). The latter (indirectly) proves the understanding of non-price factors as the sources of CAs in firms; all the factors defined by factor analysis (with the exception of location and export share/ factor 1) show positive and statistically significant correlation between CAs (see Table 6). Again further analysis showed that companies which evaluate the factors (non-price factors) above average, realize higher CAs on international markets. This again proves the acceptance of $\mathrm{H} 2$. On the other hand the multiple regression analysis did not bring the expected results - the influence on CAs can be proved only for two out of five factors defined by factor analysis (factor 1 (innovation/flexibility) and 2 (knowledge)) (see Table 7). The reason for such a result can be hidden in the dependency of the variables of the non-price factors. Some variables cannot influence only one factor, but also several other non-price factors.

Also we cannot deny the influence of separate factors on CAs nor their group influence (price/non-price) (see also Table 2, $4 \mathrm{a}-\mathrm{c}$ ). According to this fact $\mathrm{H} 3$ can be also accepted.

Among interesting results of the analysis was also the fact that $81 \%$ of the companies claimed that their CAs are sustainable, which shows surprisingly high level of understanding of CAs in firms. 
Table 5: Results of Factor Analysis: Communalities and Factor Weights

\begin{tabular}{|l|c|c|c|c|c|c|}
\hline \multicolumn{1}{|c|}{ Variables of non-price factors } & Commu & Factor & Factor & Factor & Factor & Factor \\
$\mathbf{1}$ & $\mathbf{2}$ & $\mathbf{2}$ & $\mathbf{7}$ & $\mathbf{4}$ & $\mathbf{5}$ \\
$\mathbf{( F l e x )}$ & $\mathbf{K N}$ & $\mathbf{Q Y}$ & $\mathbf{L O}$ & $\mathbf{H R}$ \\
\hline Rareness & & & & \\
\hline Inimitability of HR & .043 & .021 & .085 & .018 & -.188 & -.024 \\
\hline Commitment of HR & .170 & .128 & .049 & -.048 & -.165 & .289 \\
\hline Motivation of HR & .770 & -.187 & .089 & .033 & -.008 & .913 \\
\hline Goals achievements & .677 & -.015 & -.018 & -.059 & .001 & .860 \\
\hline Corporate culture & .635 & -.027 & -.003 & .053 & .012 & .788 \\
\hline Adaptation of HR to changes & .556 & .240 & .131 & .108 & -.004 & .481 \\
\hline Capabilities of management & .569 & .396 & -.002 & .080 & .032 & .431 \\
\hline Substitutability of HR & .643 & .295 & .026 & -.059 & .104 & .620 \\
\hline Added value & .221 & -.056 & .331 & .255 & .005 & .033 \\
\hline Tacit KN & .396 & .044 & .533 & -.054 & .043 & .204 \\
\hline Influence of KN on product development & .554 & -.019 & .750 & .027 & .027 & -.032 \\
\hline Adaptation to environment changes & .306 & -.019 & .011 & .011 & .551 & .016 \\
\hline Localization of skills and capabilities & .750 & .064 & .358 & -.063 & .793 & -.169 \\
\hline Quality of the product & .867 & .029 & -.047 & .926 & -.072 & .015 \\
\hline Reliability of the quality & .941 & -.021 & .081 & .974 & -.010 & -.058 \\
\hline TQM & .556 & .231 & .166 & .368 & .135 & .254 \\
\hline Immobility of HR & .130 & -.376 & -.001 & .164 & .030 & .048 \\
\hline Flexibility of HR & .352 & .384 & -.060 & .178 & .258 & .151 \\
\hline Capabilities to innovate & .640 & .569 & .042 & .241 & -.108 & .153 \\
\hline Innovation improvements & .450 & .347 & .196 & .066 & -.022 & .283 \\
\hline Flexibility to environment changes & .687 & .640 & .057 & .212 & -.039 & .130 \\
\hline Environment initiatives & .530 & .530 & .157 & .128 & .043 & .139 \\
\hline Reagibility to environment incentives & .725 & .586 & .012 & .341 & -.027 & .147 \\
\hline Information initiatives & .721 & .470 & .077 & .376 & -.053 & .211 \\
\hline Networking and relationships & .620 & .517 & -.005 & .382 & -.062 & .105 \\
\hline
\end{tabular}

\footnotetext{
${ }^{4}$ The variable rareness was excluded from the analysis, because of low weight and undefined allocation on factors.
} 
Table 6: Correlations Between Factors (of Factor Analysis) and Dependent Variables

\begin{tabular}{|l|c|r|r|r|r|r|}
\hline & & $\begin{array}{c}\text { Factor 1 } \\
\text { IN/TI } \\
(\text { Flex })\end{array}$ & $\begin{array}{c}\text { Factor 2 } \\
\text { KN }\end{array}$ & $\begin{array}{c}\text { Factor 3 } \\
\text { QY }\end{array}$ & $\begin{array}{c}\text { Factor 4 } \\
\text { LO }\end{array}$ & $\begin{array}{c}\text { Factor 5 } \\
\text { HR }\end{array}$ \\
\hline EXPORT 98 & $\mathrm{r}$ & .089 & .348 & .193 & .026 & .240 \\
\hline & $\mathrm{P}$ & .173 & .000 & .019 & .391 & .005 \\
\hline ROE & $\mathrm{r}$ & .324 & .327 & .224 & -.024 & .239 \\
\hline & $\mathrm{P}$ & .000 & .000 & .009 & .402 & .005 \\
\hline Market Share & $\mathrm{r}$ & .219 & .244 & .234 & .009 & .246 \\
\hline & $\mathrm{P}$ & .022 & .012 & .016 & .469 & .012 \\
\hline
\end{tabular}

Sig. 1-tailed; $P \leq 0.05$

Table 7: The Results of the Multiple Regression Analysis

\begin{tabular}{|l|c|c|c|c|c|c|c|c|}
\hline & Constant & & Factor 1 & Factor 2 & Factor 3 & Factor 4 & Factor 5 & \multirow{2}{*}{$\mathrm{R}^{2}$} \\
\hline \multirow{2}{*}{ Export 98 } & \multirow{2}{*}{67.351} & $\mathrm{~b}_{\mathrm{j}}$ & -2.955 & 7.173 & 1.693 & -.150 & 4.493 & \multirow{2}{*}{.154} \\
\cline { 3 - 9 } & & $\mathrm{P}$ & .274 & .003 & .465 & .949 & .116 & \\
\hline \multirow{2}{*}{ ROE } & \multirow{2}{*}{0.0189} & $\mathrm{~b}_{\mathrm{j}}$ & .051 & .051 & .017 & -.002 & -.007 & \multirow{2}{*}{.170} \\
\cline { 3 - 9 } & & $\mathrm{P}$ & .027 & .016 & .368 & .919 & .761 & \\
\hline \multirow{2}{*}{ Market Share } & \multirow{2}{*}{24.074} & $\mathrm{~b}_{\mathrm{j}}$ & 2.435 & 3.139 & 2.699 & .498 & 2.102 & \multirow{2}{*}{.103} \\
\cline { 3 - 9 } & & $\mathrm{P}$ & .457 & .283 & .338 & .854 & .548 & \\
\hline
\end{tabular}

Sig. 1-tailed; $P \leq \mathbf{0 . 0 5}$; bj- partial regression coefficient

\section{Conclusion}

The explanation of the most important results of the research leads us to some important conclusions about gaining CAs on international markets. Firstly, the concept of price and non-price sources of CAs is a sensible and acceptable mechanism for development of CAs in exporting firms. Secondly, the empirical analysis showed that firms differentiate between price and non-price factors of competitiveness which makes the concept and its issues theoretically and empirically acceptable. This also means that R-A theory of competition gives rational contemporary base for the definition of CA sources. For example, for Slovenian export manufacturing firms turned out that those firms which understand the meaning of non-price factors and invest and develop them gain higher CA; better position and performance on international markets; and therefore better export results. This gives us a good reason to accept the concept of price and non-price factors as an up-to-date concept of gaining advantages in export companies. Also we can say that both price and non-price factors 
contribute to CA on international markets, while according to the research we can prove that non-price factors play a major role in their gaining.

\section{References}

Aaby, N.E./ Slater, S.F. (1989): Management Influences on Export Performance: A Review of the Empirical Literature 1978-88, in: International Marketing Review, No. 6, 4, pp 723.

Aldington Report (1985): Report from the Selected Committee of the House of Lords on Overseas Trade, London, House of Lords.

Andriani, Pierpaolo/ Hall, Richard (1998): Management Focus. Analysing Intangible Resources and Managing Knowledge in a Supply Chain Context, in: European Management Journal, No. 6, pp 685-697.

Balassa, B. (1985): Recent Developments in the Competitiveness of American Industry and Prospects for the Future. in: Balassa B., (ed.): Changing Patterns in Foreign Trade and Payments, New York, Norton.

Barney, Jay B. (1991): Firm Resources and Sustained Competitive Advantage, in: Journal of Management, No. 1, pp 99-120.

Barney, Jay B. (1986): Organizational Culture: Can It Be a Source of Sustained Competitive Advantage? in: Academy of Management Review, No.11, pp 656-665.

Belcher, A./ Hassard, J./ Procter, S.J. (1996): R\&D Decisions. Strategy, Policy and Innovations, London, Routledge, 287 p.

Bharadwaj, S./ Varadarajan, P./ Fahy, J. (1993): Sustainable Competitive Advantage in Services Industries: A Conceptual Model and Research Propositions, in: Journal of Marketing, 57 (October), pp 83-99.

Broderick, G./ Hooley, G./ Möller, K. (1998): Competitive Positioning and the Resourcebased View of the Firm, in: Journal of Strategic Marketing, No. 6, pp 97-115.

Buckley, Peter J./ Pass, L.C./ Prescott, Kate (1988): Measures of International Competitiveness: A Critical Survey, in: Journal of Marketing Management, No. 4, 2, pp 175-200.

Cole, R.E./ Bacdayan, P. / White, J.B.(1993): Quality, Participation and Competitiveness, in: California Management Review, No. 35, 3, pp 68-81.

Conner, K.P. (1991): A Historical Comparison of Resource-based Theory and Five Schools of Thought Within Industrial Organization Economics: Do We Have a New Theory of the Firm? in: Journal of Management, No. 17, pp 121-154.

Day, George S./ Nedungadi, Prakash (1994): Managerial Representations of Competitive Advantage, in: Journal of Marketing, No. 58, pp 31-44.

Diamantopoulus, A. (1999): Export Performance Measurement: Reflective Versus Formative Indicators, in: International Marketing Review, No. 6, pp 444-457.

Dierickx, I./ Cool, K. (1989): Asset Stock Accumulation and Sustainability of Competitive Advantage, in: Management Science, No. 35, pp 1504-1511. 
Dyer, Lee (1993): Human Resources as a Source of Competitive Advantage, in: Working Paper 1993-18, Center for Advanced Human Resource Studies, 34 p.

European Management Forum (1984): Report on Industrial Competitiveness, Geneva, EMF.

Fahy, John/ Smithee, Alan (1999): Strategic Marketing and the Resource-based View of the Firm, in: Academy of Marketing Science Review, No.10, pp 1-29.

Feigenbaum, A. V. (1992/93): Thinking, Acting and Deciding: How to Address the Invisible Forces of International Competition, in: National Productivity Review, No.12, 1, pp 913.

Gale, Bradley T. (1994): Customer Satisfaction: Relative to Competitors - Is Where It's At, in: Marketing and Research Today, No. 22 1, pp 39-53.

Glazer, Rashi (1991): Marketing in an Information-intensive Environment: Strategic Implications of Knowledge as an Asset, in: Journal of Marketing, No.55, 4, pp 1-19.

Grant, Robert M. (1991): The Resource-based Theory of Competitive Advantage: Implications for Strategy Formulation, in: California Management Review, No. 3, pp 114-135.

Gummesson, E. (1994): Making Relationship Marketing Operational. in: International Journal of Service Industry Management, No. 5, pp 5-20.

Hall, Richard (1991): The Contribution of Intangible Resources to Business Success, in: Strategic Management Journal, No. 4, pp 41-51.

Hall, Richard (1992): The Strategic Analysis of Intangible Resources, in: Strategic Management Journal, No. 13, pp 135-144.

Hall, Richard (1993): A Framework Linking Intangible Resources and Capabilities to Sustainable Competitive Advantage, in: Strategic Management Journal, No. 8, pp 607618.

Hughes, K. (ed): The Future of UK Competitiveness and the Role of Industrial Policy, London, Policy Studies Institute.

Hunt, D. Shelby/ Morgan, M. Robert (1995): The Comparative Advantage Theory of Competition, in: Journal of Marketing, No. 59, pp 1-15.

Hunt, D. Shelby/ Morgan, M. Robert (1996): The Resource- advantage Theory of Competition: Dynamics, Path Dependencies and Evolutionary Dimensions, in: Journal of Marketing, No. 60, pp 107-114.

Hunt, D. Shelby (1995a): The Comparative Advantage Theory of Competition, in: Journal of Marketing, No. 59, pp 1-15.

Hunt, D. Shelby (1995b): The Resource-advantage Theory of Competition. Toward Explaining Productivity and Economic Growth, in: Journal of Management Inquiry, No. 4, pp 317-332.

Hunt, D. Shelby (1997a): Competing Through Relationships: Grounding Relationships Marketing in Resource-advantage Theory, in: Journal of Marketing Management, No. 13, pp1-15.

Hunt, D. Shelby (1997b): Resource-advantage Theory: A Snake Swallowing Its Tail or a General Theory of Competition? in: Journal of Marketing, No. 61, pp 74-82. 
Hunt, D. Shelby (1997c): Resource-advantage Theory: An Evolutionary Theory of Competitive Firm Behavior? in: Journal of Economic Issues, XXXI , No. 1, pp 59-77.

Hunt, D. Shelby (1999): The Strategic Imperative and Sustainable Competitive Advantage: Public Policy Implications of Resource-advantage Theory, in: Journal of the Academy of Marketing Science, No. 2, pp 144-160.

Huseman, R./ Goodman, J (1999): Leading with Knowledge. The Nature of Competition in $21^{\text {st }}$ Century, London, Sage Publications.

International Institute for Management Development (IMD): The World Competitiveness Yearbook, Lousanne, IMD, 1996-1998.

Itami, H./ Roehl, T.W. (1987): Mobilizing Invisible Assets, Cambridge, Harvard University Press.

Kravis, Irving B./ Lipsey, Robert E. (1971): Price Competition in the World Trade, London, NBER.

Kravis, Irving B./ Lipsey Robert E. (1992): Sources of Competitiveness of the United States and of Its Multinational Firms, in: The Review of Economics and Statistics, LXXIV, No. 2, pp 193-201.

Lippman, S.A./ Rumelt, R.P. (1982): Uncertain Imitability: An Analyiss of Interfirm Differences in Efficiency Under Competition, in: The Bell Journal of Economics, No. 13 , pp 418-438.

Mahoney, J.T. (1995): The Management of Resources and the Resource of Management, in: Journal of Business Research, No. 33, 2, pp 91-101.

Morgan, R./ Hunt, S. (1999): Relationship-based Competitive Advantage: The Role of Relationship Marketing in Marketing Strategy, in: Journal of Business Research, No. 46, pp 281-290.

Nelson, R./ Winter, S.G. (1982): An Evolutionary Theory of Economic Change, Cambridge, Belknap Press.

Oliver, Christine (1997): Sustainable Competitive Advantage: Combining Institutional and Resource-based Views, in: Strategic Management Journal, No. 18, pp 697-713.

Penrose, E.T. (1959): The Theory of The Growth of The Firm, Oxford, Basil Blackwell.

Peteraf, Margaret A. (1993): The Cornerstones of Competitive Advantage: A Resource-based View, in: Strategic Management Journal, No. 3, pp 179-191.

Pfeffer, Jeffrey (1994): Competitive Advantage Through People, in: Management Review, No 2, pp 5-23.

Piercy, Nigel (1982): Export Strategy: Markets and Competition, London, George Allen and Uniwin.

Prahalad, C.K./ Hamel, Gary (1990): The Core Competence of the Corporation, in: Harvard Business Review, Boston, No. 3, pp 79-81.

Porter, M., Dunning, J., Teece, D. (1998): Competitiveness Reevaluated, in: Das, M (ed.): Symposium on Competitiveness, Boston, Academy of Management.

Rao, V.R./ Steckel, J.H. (1998): Analysis for Strategic Marketing, Addison Wesley, 514 p. 
Shapiro, C. (1989): The Theory of Business Strategy, in: The RAND Journal of Economics, No. 20, 1, pp 125-137.

Teece, David J. (1998): Capturing Value from Knowledge Assets: The New Economy, Markets for Know-how and Intangible Assets, in: California Management Review, No. 40, 3, pp 55-79.

Thurow, L. (1992): Who Owns the Twenty-first Century? in: Sloan Management Review, Boston, Spring, pp 5-17.

Tyson, L. (1992): Trade Conflict in High-technology Industries, Washington, Institute for International Economics.

Vives, X. (1990): Information and Competitive Advantage, in: International Journal of Industrial Organization, No. 8, pp 17-35.

Wernerfelt, Birger (1984): A Resource-based View of the Firm, in: Strategic Management Journal, No. 5, pp 171-180.

Wernerfelt, Birger (1995): The Resource-based View Of The Firm: Ten Years After, in: Strategic Management Journal, No. 16 (March), pp 171-174.

Williams, Jeffrey R. (1992): How Sustainable Is Your Competitive Advantage, in: California Management Review, No. 34 (Spring), pp 29-51.

World Economic Forum (WEF): The Global Competitiveness Report 1997-2000, Geneva, World Economic Forum.

Zahra, Shaker A. (1999): The Changing Rules of Global Competitiveness in the $21^{\text {st }}$ Century, in: The Academy of Management Executive, No. 13, 1, pp 36-42. 